Ministerstwo Nauki

i Szkolnictwa Wyższego

Digitalizacja archiwalnych numerów czasopisma naukowego Analecta Cracoviensia 1-24 (1969-1992)

i ich publikacja w otwartym dostępie - zadanie finansowane w ramach umowy 672/P-DUN/2017 ze środków

Ministra Nauki i Szkolnictwa Wyższego przeznaczonych na działalność upowszechniającą naukę

\title{
ZNACZENIE SOBOROWEJ KONCEPCJI KAPEANSTWA DLA SPECYFIKACJI ZNAKÓW POWOŁANIA
}

II Sobór Watykański przyczynił się w znacznej mierze do zmiany obiegowych poglądów na postać i posługę kapłana w Kościele. O ile dawniej, przed Soborem, spoglądano na księdza jako na przedstawiciela hierarchii kościelnej, który z samej natury rzeczy zajmuje miejsce p o n ad zwykłymi wiernymi, to postępujący i zaaprobowany w pewnej mierze przez Sobór, ale często źle rozumiany, proces demokratyzacji Kościoła sprawił, że kapłana traktuje się - nie tylko w jego życiu codziennym, ale także w sprawowanej przezeń funkcji sakralnej - na równi $\mathrm{z}$ wiernymi świeckimi. Sytuacja taka wpływa niekorzystnie nie tylko na samych księży przeżywających niejednokrotnie kryzys własnej tożsamości, ale również na tych młodych ludzi, którzy w głębi serca odkrywają powołanie Boże: pójdź za Mna. Toteż w pełni zrozumiałą staje się rzeczą, że zarówno papież Paweł VI, jak też Jan Paweł II, wracają niejednokrotnie $\mathrm{w}$ swoich przemówieniach do problemu ,identyczności kapłana".

Papież Paweł VI zdawał sobie dobrze sprawę z kryzysu kapłaństwa i powołań kapłańskich, jaki się ujawnił z wielką siłą po II Soborze Watykańskim ${ }^{1}$. Swiadczą o tym m. in. jego stopniowane pytania: „Kim więc jest kapłan? [...] Czy istnienie kapłaństwa w ekonomii Nowego Testamentu jest usprawiedliwione? [...] A dalej, dokonujący się niepowstrzymanie proces desakralizacji, sekularyzacji, który przenika i przekształca współczesny świat - czyż zostawia jeszcze miejsce i rację bytu kapłanowi w społeczeństwie zajętym przede wszystkim sprawami do-

1 Por. E. Pin, Zróżnicowanie funkcji kapłańskiej, „Concilium” 1-5 (1969), 178 186; A. Leault, La nouveauté des perspectives offertes par Vatican II sur le ministère et la vie des prêtres, [w:] Le pretre hier, aujourd'hui, demain, Montréal-Paris 1970, 206-219; Kard. K. Wojtyła, Teologiczne podstawy duszpasterskiej misji kapłana, [w:] Osobowość kaptańska. Praca zbiorowa pod red. ks. J. Majki, Wrocław 1976, 65 mn.; J. Salij, Paradoksy powołania $i$ życia kapłańskiego, „Ateneum Kapłańskie" 86 (1976) $189 \mathrm{nn}$. 
czesnymi i świeckimi? Czy jest miejsce dla kapłana, który jest nastawiony na sprawy transcendentne i eschatologiczne, które jakże bardzo są obce doświadczeniu człowieka świeckiego? Wątpliwości narastają jeszcze: czy istnienie kapłaństwa takiego, jakie zostało określone kanonicznie - czy ma ono oparcie we wczesnej świadomości chrześcijańskiej? Wątpliwości osiągają punkt krytyczny także i w innych jeszcze aspektach, tj. psychologicznym i socjologicznym: Czy, mianowicie, kapłaństwo jest jeszcze w ogóle możliwe? Czy jest pożyteczne? Czy może ono stać się treścią ofiarnego i bohaterskiego powołania? Czy może ono jeszcze stanowić pewien rodzaj życia, który by nie powodował frustracji ani alienacji? Młodzi ludzie stawiają te pytania natarczywie. Wielu z nich traci otuchę. Ileż to powołań zostało zmarnowanych przez tę złośliwą wichurę! Pytania takie stawiają sobie ludzie młodzi i przeżywają udrękę wewnętrzną, która przenika do głębi serca tych, co się już zaangażowali w kapłaństwo" ${ }^{2}$.

Przy innej okazji tenże sam papież stwierdzał, że rozliczne pytania stawiane pod adresem kapłaństwa po II Soborze Watykańskim wiążą się z jedną, zasadniczą sprawą tożsamości kapłańskiej, z pytaniem: „Kim jest kapłan? Czy w religii chrześcijańskiej istnieje prawdziwe kapłaństwo? A jeżeli istnieje jakieś kapłaństwo służebne według Ewangelii, to jaką postawę ma przybrać kapłan? Wszystkie pokusy protestanckiej kontestacji narzucają się tu $\mathrm{z}$ całą siłą. A być może także, iż mamy tu do czynienia $\mathrm{z}$ jeszcze trudniejszymi pokusami pochodzącymi $\mathrm{z}$ innego świata - chociaż to jest tajemnicą. Pokusa ta jednak nie jest wcale chimeryczna - dotyczy zwątpienia, które nie jest tylko wątpieniem metodycznym, ale jest czymś w rodzaju zasmucającej odpowiedzi na pytanie o prawdę, której się nie umiało zdobyć. Pokusa skłania do niepewności, posuniętej aż do zaślepienia, które przybiera postawę dramatyczną i jakby arystokratyczną w umysłach pozbawionych od tej chwili. światła wewnętrznego. Te pokusy wcisnęły, się aż do dna świawomości kapłana, aby podważyć w nim pewność jego statusu kościelnego: „Tyś jest kapłanem na wieki”. Pragnie się zastąpić tę pewność obsesyjnym pytaniem: kim ja jestem? Czyż nie wystarczała odpowiedź Kościoła dawana zawsze? Była ona stale przekazywana w czasie lat studiów seminaryjnych. Płonęła jak lampa niegasnąca w samym centrum naszej duszy i była czymś w rodzaju prawdy wrodzonej w naszym umyśle. Wspomniane pytanie jest z pewnością, i na pierwszy rzut oka, zbędne i niebezpieczne zarazem. Faktem jest jednak to, że zo-

2 Paweł VI, Kapłaństwo dzisiaj, Poznań 1978, 80-81 (przemówienie do proboszczów, duszpasterzy i seminarzystów Rzymu, wygłoszone 20 II 1971).

3 Tamże, 108 (przemówienie do proboszczów oraz kaznodziejów wielkopostnych, wygloszone 17 II 1972). 
stało ono postawione i utkwiło jak strzała wbita w serce wielu kapłanów, a przede wszysttkim wielu młodych stojących u progu święcen" " 3 .

Diagnoza, jaką papież Paweł VI stawiał w odniesieniu do sytuacji kapłaństwa w Kościele, nie była wcale pocieszająca. Nie trzeba jednak zbytnio się trudzić, by dowieść jej prawdziwości: realia świata zachodniego 'w pełni ją potwierdzają. Aktualny kryzys powołań w krajach Europy zachodniej wiąże się ściśle z zakwestionowaniem identyczności i niepewnością co do miejsca przysługującego kapłanowi w Kościele. Rzeczą nie podlegającą dyskusji jest natomiast fakt, że sama wizja kapłaństwa wpływa w znacznej mierze na dobór i jakość powołań kapłańskich. Zastanówmy się więc nad tą wizją podaną przez sam II Sobór Watykański i nad jej konsekwencjami praktycznymi; analiza bowiem taka rzuci niewątpliwie jakieś światło na konkretne ,znaki powołania".

\section{PRZYCZYNY KRYZYSU TOŻSAIMOŚCI KAPEAÑSIKIEJ}

$\mathrm{Na}$ plan pierwszy $\mathrm{w}$ naszym studium wysuwa się pytanie dotyczące przyczyn krýzysu tożsamości kapłańskiej. Trudno byłoby oczywiście dać w tym miejscu wyczerpującą na nie odpowiedź. Niektóre źródła kryzysu, zwłaszcza związane z II Soborem Watykańskim, są jednak same przez się widoczne. Chodzi mianowicie o nowe spojrzenie na Kościół - lud Boży, na zbarwienie i na samo kapłaństwo.

II Sobór Watykański potraktował przede wszystkim Kościół jako wspólnotę Ludu Bożego, w której różnorodność posług nie przekreśla podstawowej równości wszystkich dzieci Bożych. Zaakcentowana wprawdzie została, w dokumentach soborowych, hierarchia kościelna ${ }^{4}$, nie przeszkodziło to jednak Soborowi stwierdzić, iż wspólna jest w Kościele ,godność członków wynikająca z ich odrodzenia się w Chrystusie, wspólna łaska synów, wspólne powołanie do doskonałości, jedno zbawienie, jedna nadzieja i miłość niepodzielna" (KK 32), oraz dodać, że chociaż „niektórzy z woli Chrystusa ustanawiani są nauczycielami, szafarzami tajemnic i pasterzami innych, to jednak co się tyczy godności i wspólnej wszystkim wiernym działalności około budowania Ciała Chrystusowego, prawdziwa równość panuje wśród wszystkich. Albowiem rozróżnienie, które położył Pan między szafarzami świętymi a resztą Ludu Bożego, niesie z sobą łączność, gdyż pasterze i pozostali wierni związani są z sobą przez konieczne, wzajemne odniesienia; pasterze Kościoła, idąc za przykładem Pana, sobie nawzajem i innym wiernym oddają posługi duchowe, wierni zaś ochoczo świadczą wspól-

\footnotetext{
${ }^{4}$ Por. KK 18 nn.; DB $2 \mathrm{nn}$.
} 
nie pomoc pasterzom i nauczycielom. Tak to w rozmaitości dają świadectwo jedności przedziwnej w Ciele Chrystusowym" (KK 32).

Przytoczony tekst soborowy wskazuje niedwuznacznie na jedność Ludu Bożego przy równoczesnej różnorodności zadań i funkcji spoczywających na posżczególnych jego członkach. Odczytywany jednak jednostronnie tekst ten może być rozumiany jako poparcie dla fałszywie pojętej demokracji w Kościele. Nie jest rzeczą wykluczoną, że na tej i tym podobnych wypowiedziach soborowych oparli swe sugestie rzecznicy wprowadzenia całkowitej demokratyzacji do Kościoła ${ }^{5}$. Niewątpliwym oparciem dla ich twierdzeń była $\mathrm{z}$ kolei soborowa koncepcja zbawienia.

Przezwyciężając dawną, neoplatońską i pseudodionizjańską mentalność II Sobór Watykański ukazał zbawienie nie jako rzeczywistość zstępującą z góry - od Boga, za pośrednictwem hierarchii, na wiernych jak to niemal powszechnie dawniej głoszono, ale jako obecne stale $\mathrm{w}$ Kościele - tym ,,powszechnym sakramencie zbawienia” (KDK 45). Sobór spojrzał ponadto na zbawienie bardziej egzystencjalnie twierdząc, że polega ono na przylgnięciu człowieka do Boga, na rozwoju życia Bożego w człowieku, na ścisłym zespoleniu osoby ludzkiej z Chrystusem, z Jego zbawczą śmiercią i zmartwychwstaniem. W ujęciu soborowym zbawienie zaczyna się faktycznie na ziemi, realizuje się w Kościele i poprzez Kościól, a więc w teraźniejszości i to przy czynnym zaangażowaniu wszystkich zainteresowanych, kres zaś swój osiąga dopiero w wieczności. Wówczas to bowiem śmierć „zostanie przezwyciężona”, a ,„wszechmocny i miłosierny Zbawca przywróci człowiekowi zbawienie z jego winy utracone" (KDK 18); człowiek natomiast przylgnie do Boga ,całą swą naturą w wiecznym uczestnictwie nieskazitelnego życia Bożego" (KDK 18).

Warunkiem osiągnięcia zbawienia wiecznego jest oczywiście - zgodnie z nauką II Soboru Watykańskiego - zespolenie się człowieka z Bogiem w doczesności: przezwyciężenie własnej śmierci grzechowej, będącej następstwem grzechu pierworodnego oraz skutkiem grzechów aktualnie popełnianych, poprzez wszczepienie w zbawczą śmierć Chrystusa. Wszczepienie to dokonuje się zazwyczaj w sakramentach chrztu ${ }^{6}$ i pojednania, przekracza jednak niejednokrotnie ramy sakramentalne. Sam Sobór zwraca uwagę na ten moment, kiedy stwierdza, iż to wszystko, o czym mówił, dotyczy „nie tylko wiernych chrześcijan, ale także wszystkich ludzi dobrej woli, w których sercu działa w sposób niewidzialny łaska. Skoro bowiem za wszystkich umarł Chrystus i skoro

5 Por. K. Rahner, Demokracja w Kościele?, „Więź” 7/8 (1969), 23-36; P. Klosterman, Kirche-Ereignis und Institution, Wien 1976, $41 \mathrm{nn}$.

${ }^{6}$ Por. KK 31; DM 115, 316. 
ostateczne powołanie człowieka jest rzeczywiście jedno, mianowicie boskie, to musimy uznać, że Duch Święty wszystkim ofiarowuje możliwość dojścia w sposób Bogu wiadomy do uczestnictwa w tej paschalnej tajemnicy" (KDK 22).

Ujmując $w$ te nsposób problem zbawienia ludzi nieochrzczonych II Sobór Watykański nie tylko w nowym świetle spojrzał na dyskutowane już wcześniej zagadnienie konieczności Kościoła do zbawienia ${ }^{7}$, ale także zaakcentował egzystencjalny charakter zbawienia. Takie ustawienie zagadnienia przez Sobór nie oznacza oczywiście wcale, by dla ludzi „,dobrej woli, w których sercu działa w sposób niewidzialny łaska”, Kościół przestał być faktycznym sakramentem zbawienia. Sam Sobór bowiem podkreśla, ,opierając się na Piśmie świętym i Tradycji, że ten pielgrzymujący Kościół konieczny jest do zbawienia. Chrystus bowiem jest jedynym Pośrednikiem i drogą zbawienia. On, co stał się dla nas obecny w Ciele swoim, którym jest Kościół; On to właśnie podkreślając wyraźnie konieczność wiary i chrztu (por. Mk 16, 16; J 3, 5) potwierdził równocześnie konieczność Kościoła, do którego ludzie dostają się przez chrzest jak przez bramę" $(\mathrm{KK} 14)^{8}$. To podstawowe stwierdzenie, uzupełnione jeszcze mocnym dodatkiem, że nie mogliby być zbawieni ludzie, ,którzy wiedząc, że Kościół założony został przez Boga za pośrednictwem Chrystusa jako konieczny, mimo to nie chcieliby bądź przystąpić do niego, bądź też w nim wytrwać" (KK 14), staje się z kolei dla Soboru punktem wyjścia do szczegółowego omówienia różnych kategorii oșób (chrześcijan: katolików i niekatolików, żydów, muzułmanów oraz członków innych religii niechrześcijańskich) w ich relacji do Kościoła. Duchowy charakter więzi z Kościołem został przy tym mocno zaakcentowany. Sobór nie waha się bowiem twierdzić, że nawet katolik, a więc człowiek „wcielony do Kościoła”, nie dostępuje zbawienia, o ile nie trwa w miłości, czyli o ile ,pozostaje wprawdzie w łonie Kościoła ",ciałem”, ale nie ,sercem” (KK 14). Z drugiej zaś strony Sobór podkreśla, że Opatrzność Boża nie odmawia „koniecznej dla zbawienia pomocy takim, którzy bez własnej winy w ogóle nie doszli jeszcze do wyraźnego poznania Boga, a usiłują, nie bez łaski Bożej, wieść uczciwe życie" (KK 16).

To egzystencjalne ujęcie zbawienia, które realizuje się w Kościele i poprzez Kościół (nie utożsamiany jednak wcale z hierarchią kościelną), wiąże się dosyć ściśle z doktryną II Soboru Watykańskiego o kró-

7 Por. J. Ratzinger, Salus extra Ecclesiam nulla est, ,Znak” 17 (1965), 611-618; B. Pylak, Zbawcza funkcja Kościola w konstytucji "Lumen gentium», „Zeszyty Naukowe KUL" 9 (1966) z. 3, 11-22; Y. Congar, Chrystus i zbawienie świata, Kraków 1968, 257 nn.; H. Lais, Poza Kościołem nie ma zbawienia, [w:] Dlaczego wierzymy?, Warszawa 1969, 314-3|23.

8 Por. też DA 6; DM 6; KDK 40. 
lewskim kapłaństwie Ludu Bożego. Sobór stwierdza mianowicie, że ludzie są poświęcani „przez odrodzenie i namaszczenie Duchem Swiętym”, jakie się dokonuje w sakramencie chrztu św., ,jako dom duchowy i święte kapłaństwo, aby przez wszystkie właściwe chrześcijaninowi uczynki składać ofiary duchowe i głosić moc Tego, który wezwał ich z ciemności do swego przedziwnego światła" (KK 10), dodając w formie uzasadnienia, że sam Chrystus - ten „najwyższy i przedwieczny Kapłan" daje tym wszystkim, których przez chrzest wiąże ściśle z życiem i posłannictwem swoim, „również udział w swej funkcji kapłańskiej (munus sacerdotale) dla sprawowania kultu duchowego, aby Bóg był wielbiony, a ludzie zbawiani" (KK 34). Kapłaństwo wiąże się bowiem jak najściślej - w ujęciu soborowym - z ofiarą, i to $\mathrm{z}$ ofiarą składaną z samego siebie, a więc mającą tym samym wartość zbawczą.

Gruntowna analiza myśli soborowej na temat godności kapłańskiej Ludu Bożego prowadzi do wniosku, że II Sobór Watykański, przezwyciężając dawną, socjologiczną koncepcję kapłaństwa, zgodnie z którą „kapłanami” we właściwym tego słowa znaczeniu byliby tylko przedstawiciele hierarchii kościelnej, spojrzał na kapłaństwo na płaszczyźnie teologicznej: ukazał jedyne i wiecznotrwałe kapłaństwo Chrystusa, w którym uczestniczą na swój sposób zarówno przedstawiciele hierarchii kościelnej, jak i wierni świeccy ${ }^{9}$. „Kapłan urzędowy mianowicie, dzięki władzy świętej, jaką się cieszy, kształci lud kapłański i kieruje nim, sprawuje w zastępstwie Chrystusa (in persona Christi) Ofiarę eucharystyczną i składa ją Bogu w imieniu całego ludu; wierni zaś na mocy swego królewskiego kapłaństwa współdziałają w ofiarowaniu Eucharystii; pełnią też to kapłaństwo przez przyjmowanie sakramentów, modlitwę i dziękczynienie, świadectwo życia świątobliwego, zaparcie, się siebie i czynną miłość" (KK 10).

Chociaż oba wymienione wyżej rodzaje kapłaństwa różnią się między sobą ,,istotą a nie stopniem tylko" (KK 10), nie wynika stąd jednak wcale, by II Sobór Watykański uznał - w ślad za teologią tradycyjną - kapłaństwo księży za właściwe. Wprost przeciwnie, liczne teksty soborowe akcentujące rolę wspólnotowego kapłaństwa wiernych w Kościele oraz ścisły jego związek $\mathrm{z}$ ofiarą osobistą, wewnętrzną ${ }^{10}$ ukazują właśnie to królewskie kapłaństwo jako bardziej zasadnicze, podstawowe, które dla swej aktualizacji wymaga posługi kapłanów hierarchicznych ${ }^{11}$. Jeżeli zatem, przykładowo, II Sobór Watykański ukazuje

9 Por. A. Krupa, Kapłaństwo Chrystusa, [w:] Osobowość kapłańska, jw., 1954; L. Balter, Duchowość kapłańska we wspótczesnej kulturze, „Ateneum Kapłańiskie" 816 (1976), 2213 nn.

10 Por. KL 12, 48; KK 10 n., 34; DA 3; DM 15; DK 2 nn.

11 Por. L. Baliter, Kapłan ministerialny w kapłańskiej wspólnocie Ludu Boże- 
liturgię jako „wykonywanie kapłańskiego urzędu Jezusa Chrystusa” (KL 7) ${ }^{12}$ przez cały Lud Boży: księży i wiernych świeckich, to zaznacza równocześnie, iż obowiązkiem duszpasterzy jest czuwanie nad tym, ,aaby czynności liturgiczne odprawiano nie tylko ważnie i godziwie, lecz także aby wierni uczestniczyli w nich świadomie, czynnie i owocnie" (KL 11). Kościół bowiem ,bardzo się troszczy o to, aby chrześcijanie podczas tego misterium wiary nie byli obecni jak obcy i milczący widzowie, lecz aby przez obrzędy i modlitwy tę tajemnicę dobrze zrozumieli, w świętej czynności uczestniczyli świadomie, pobożnie i czynnie [...], a ofiarując niepokalaną hostię nie tylko przez ręce kapłana, lecz także razem z nim, uczyli się samych siebie składać w ofierze" (KL 48).

Te i tym podobne wypowiedzi II Soboru Watykańskiego pozwoliły niżej podpisanemu zaproponować już przed laty ${ }^{13}$ dwie nowe, teologiczne definicje kapłaństwa i ofiary, określające kapłaństiwo jako „właściwość osoby, mocą której może ona wykonywać pośredniczenie ofiarnicze”, ofiarę zaś jako ,dany Bogu.dar z siebie samego za innych", oraz stwierdzić wyraźnie, iż uwzględniając to podstawowe znaczenie terminu „kapłan” można „,mówić o trzech tylko rodzajach kapłaństwa w Kościele, a mianowicie o kapłaństwie Chrystusa, niższym od niego kapłaństwie Matki Bożej i jeszcze niższym kapłaństwie wszystkich innych członków Mistycznego Ciała, a więc hierarchii łącznie z wiernymi" ${ }^{14}$. Rzeczywistość zmienia się oczywiście, skoro weźmie się pod uwagę fakt ustanowienia przez Chrystusa hierarchii w Kościele. Chrystus mianowicie raz tylko złożył krwawą ofiarę ze siebie. Chcąc zaś ciągle ją powtarzać po całej ziemi, wybrał grono osób, którym powierzył władzę ponawiania w bezkrwawy sposób swojej jedynej ofiary. Można zatem powiedzieć, że kapłani hierarchiczni, których kapłaństwo wiąże się ściśle $\mathrm{z}$ Eucharystią $\mathrm{i}$ - jak stwierdza św. Tomasz ${ }^{15}$ - jest skierowane albo do konsekracji, albo do posługi związanej $\mathrm{z}$ tym sakramentem, spełniają w Ludzie Bożym ,jedyną i sobie tylko właściwą rolę, dla spełnienia której muszą być uprzednio wszczepieni w samo kapłaństwo Chrystusa. Swięcenia kapłańskie dają im coś nowego, coś, co można by nazwać właśnie bezpośrednim udziałem w samym kapłaństwie Chrysstusa, czyniąc $\mathrm{z}$ nich po prostu podatne narzędzia, których usługi w

go, [w:] W kierunku prawdy. Praca zbiorowa pod red. bpa B. Bejze, Warszawa 1976, $179 \mathrm{nn}$.

12 Por. L. Balter, Wspólnotwórcza rola liturgii, [w:] Człowiek we wspólnocie Kościoła. Praca zbiorowa pod red. ks. L. Baltera, Warszarwa 1979, 2512 nn.

13 Tenże, Posoborowe spojrzenie na kapłaństwo katolickie, „Homo Dei” 40 (19/7), $14 \mathrm{nn}$.

14 Tamże, 17.

15 Por. S. Thomas de Aquino, Summa theologiae, Suppl. III q. 37, a. 2. 
obecnym stanie rzeczy faktycznie warunkują działalność Chrystusowego kapłaństwa" ${ }^{16}$.

Te ogólne spostrzeżenia i uwagi dotyczące doktryny soborowej o Kościele, zbawieniu i kapłaństwie wyjaśniają w pewnej mierze to zachwianie się równowagi wewnętrznej u wielu księży, o jakim wspominał niejednokrotnie pap. Paweł VI. Jednym z warunków przezwyciężenia zaistniałego $\mathrm{w}$ Kościele kryzysu będzie niewątpliwie gruntowniejsze zapoznanie się z modelem kapłana ministerialnego, naszkicowanym przez II Sobór Watykański.

\section{KAPEAN MINISTERIALNY W UJĘCIU II SOBORU WATYKAŃSKIEGO}

II Sobór Watykański kreśląc w swych dokumentach nową wizję Kościoła Chrystusowego ukazał Lud Boży jako ,zgromadzenie tych, co z wiarą spoglądają na Jezusa, sprawcę zbawienia i źródło pokoju oraz jedności" (KK 9). Zgromadzenie to aktualizuje się, jako takie, a więc jako wspólnota „wiary, nadziei i miłości”, wyposażona w „organa hierarchiczne” (KK 8) i będąca „powszechnym sakramentem zbawienia, ukazującym i zarazem realizującym tajemnicę miłości Boga do człowieka" (KDK 45), ilekroć jest w nim sprawowana Pamiątka śmierci i zmartwychwstania Pana. „Albowiem liturgia, przez którą - szczególnie w boskiej Ofierze Eucharystycznej - „dokonuje się dzieło naszego Odkupienia", w najwyższym stopniu przyczynia się do tego, aby wierni życiem swoim wyrażali oraz ujawniali innym misterium Chrystusa i rzeczywistą naturę prawdziwego Kościoła”, który jest „ludzki i jednocześnie boski, widzialny i wyposażony w dobra niewidzialne, żarliwy w działaniu i oddany kontemplacji, obecny $w$ świecie, a jednak pielgrzymujący” (KL 2). „Słusznie przeto uważa się liturgię za wykonywanie kapłańskiego urzędu Jezusa Chrystusa; w niej przez znaki widzialne wyraża się, i w sposób właściwy poszczególnym znakom urzeczywistnia uświęcenie człowieka, a mistyczne Ciało Jezusa Chrystusa, to jest Głowa ze swymi członkami, wykonuje całkowity kult publiczny" (KL 7).

Całe życie Kościoła, wszystkie kościelne posługi i dzieła apostolskie, pozostałe sakramenty św. - wszystko to, zdaniem II Soboru Watykańskiego, wiąże się z Eucharystią i do niej prowadzi. „W najświętszej bowiem Eucharystii zawiera się całe duchowe dobro Kościoła, a mianowicie sam Chrystus, nasza Pascha i chleb żywy, który przez Ciało swoje ożywione i ożywiające Duchem Swiętym daje życie ludziom, zapraszając ich i doprowadzając $w$ ten sposób do ofiarowania razem $z$ Nim

16 L. Balter, Posoborowe spojrzenie, 18. 
samych siebie, swojej pracy i wszystkich rzeczy stworzonych" (DK 5). Dlatego też liturgia, zwłaszcza eucharystyczna, stanowi nie tylko szczyt całej działalności Mistycznego Ciała oraz faktyczne źródło jego wewnętrznej mocy ${ }^{17}$, ale także „ośrodek zgromadzenia wiernych, któremu przewodniczy prezbiter" (DK 5). Mniej widoczna w codziennym życiu Kościoła rola kapłana ministerialnego ukazuje się właśnie w liturgii jako niezastąpiona.

O ile weźmie się pod uwagę następujące, podstawowe stwierdzenia Soboru jako przesłanki, a mianowicie, że $1^{\circ}$ „każdy obchód liturgiczny, jako dzieło Chrystusa-Kapłana i Jego Ciała, czyli Kościoła, jest czynnością w najwyższym stopniu świętą, a żadna inna czynność Kościoła nie dorównuje jej skuteczności z tego samego tytułu i w tym samym stopniu” (KL 7), $2^{\circ}$ żadna ,społeczność chrześcijańska nie da się wytworzyć, jeżeli nie ma korzenia i podstawy w sprawowaniu Najświętszej Eucharystii” (DK 6), $3^{\circ}$ każdym „należytym sprawowaniem Eucharystii kieruje biskup" ( $\mathrm{KK} 26$ ), od którego zależni są w wykonywaniu swej władzy zarówno księża, którzy ,także otrzymali święcenia na prawdziwych kapłanów Nowego Testamentu, by być skrzętnymi współpracownikami biskupów, jako też diakoni, którzy wyświęceni na ten urząd służą Ludowi Bożemu w łączności z biskupem oraz gronem jego kapłanów. Biskupi więc są głównymi szafarzami tajemnic Bożych, jako też kierownikami, krzewicielami i stróżami życia liturgicznego w powierzonym sobie Kościele" (DB 15), - wówczas wniosek o niezastąpionej roli kapłana hierarchicznego w Kościele nasuwa się sam w sposób oczyiwișty: wspólnota chrześcijańska nie może po prositu być sobą w pełni ani też realizować swojej misji w świecie bez kapłana służebnego,

Rozwijając powyższy wniosek nieco szerzej można by powiedzieć, że kapłan ministerialny jest dla kapłańskiej wspólnoty Ludu Bożego jak gdyby sakramentem, który uobecnia w niej i aktualizuje jedyne i niepowtarzalne kapłaństwo Jezusa Chrystusa z całym bogactwem Jego proroczej i królewskiej funkcji. Myśl tą wypowiada w pewnej mierze sam II Sobór Watykański, kiedy stwierdza, że Chrystus „,jest zawsze obecny w swoim Kościele, szczególnie w czynnościach liturgicznych" i dodaje w formie wyjaśnienia, iż jest On obecny „w ofierze Mszy świętej, czy to w osobie odprawiającego, gdyż „Ten sam, który kiedyś ofiarował się na krzyżu, obecnie ofiaruje się przez posługę kapłanów", czy też zwłaszcza pod postaciami eucharystycznymi. Obecny jest mocą swoją w sakramentach tak, że gdy ktoś chrzci, sam Chrystus chrzci. Jest obecny w swoim słowie..." (KL 7).

17 Por. KL 10. 
Idąc jeszcze dalej wypada stwierdzić, że to właśnie kapłan zwołuje - korzystając nierzadko z posługi swoich współpracowników - kapłański Lud Boży na liturgię, której sam przewodniczy stając się mniej lub bardziej podatnym narzędziem Chrystusa-Kapłana - jedynego autentycznego Celebransa i Pośrednika między niebiem a ziemią. Dzięki posłudze kapłana ministerialnego wreszcie wierni mogą aktualizować swoje królewskie kapłaństwo, łącząc ofiarę składaną ze swego życia z eucharystyczną Ofiarą Chrystusa. Myśli te rozwija szerzej II Sobór Watykański w Dekrecie o posłudze i życiu kapłanów, kiedy stwierdza:

„Przez apostolskie bowiem opowiadanie Ewangelii Lud Boży jest zwoływany i zgromadzany, tak że wszyscy należący do tego Ludu, będąc uświęceni przez Ducha Świętego, ofiarują samych siebie jako „ofiarę żywą, świętą, miłą Bogu" (Rz 12,1). Ponadto przez posługę prezbiterów dokonuje się duchowa ofiara wiernych $\mathrm{w}$ zjednoczeniu $\mathrm{z}$ ofiarą Chrystușa, jedynego Pośrednilka. Tę zaś ofiarę składa się bezkrwawo i sakramentalnie w Eucharystii przez ich ręce w imieniu całego Kościoła aż do czasu przyjścia samego Pana. Do tego zmierza i w tym znajduje swą pełnię posługa prezbiterów. Ich bowiem posługiwanie, które zaczyna się od głoszenia Ewangelii, czerpie swą moc z Ofiary Chrystusa i dąży do tego, by ,całe to odkupione państwo, to jest zgromadzenie i społeczność świętych, jako powszechna ofiara, zostało ofiarowane Bogu przez Wielkiego Kapłana, który w męce ofiarował także samego siebie za nas, byśmy się stali ciałem tak wielkiej Głowy" "(DK 2).

Kapłanowi ministerialnemu przysługuje zatem, zgodnie $\mathrm{z}$ wyraźną doktryną II Soboru Watykańskiego, wyjątkowa i niezastąpiona rola w społeczności wiernych. Gdyby go zabrakło, Kościół przestałby spełniać właściwą sobie funkcję powszechnego sakramentu jedności i zbawienia dla rodzaju ludzkiego, nie mógłby także mieć pewności co do własnej wierności i własnej widzialnej ciągłości ${ }^{18}$. Bez posługi kapłana ministerialnego nie mogłoby bowiem zaistnieć żadne autentyczne zgromadzenie liturgiczne, będące - zgodnie $\mathrm{z}$ nauką teologów poisoborowych ${ }^{19}$ epifanią, prawdziwym objawieniem się Kościoła, a także szczególnym znakiem zbawczej obecności Chrystusa i Kościoła w świecie.

Obok tej podstawowej i niezastąpionej roli kapłana ministerialnego w Ludzie Bożym dokumenty II Soboru Watykańskiego podkreślają rów-

18 P.or. L. Balter, Kaplan ministerialny, $1811 \mathrm{n}$.

19 Por. J. Lécuyer, Zgromadzenie liturgiczne: jego fundamenty biblijne $i$ patrystyczne, „Concilium" $1-110$ (1965-11966), 130 n.; R. Zielasko, Teologia zgromadzenia liturgicznego, [w:] Wprowadzenie do liturgii, Poznań 1967, 125-134; L. Balter, Wspólnotwórcza rola, $252 \mathrm{nn}$. 
nież jego „służebność”: kapłan jest i powinien być, z racji swego posłannictwa i pełnionych funkcji, sługą wszystkich. Sam Chrystus bowiem, którego kapłan uobecnia w zgromadzeniu wiernych, podkreślał, że nie przyszedt, aby $M u$ stużono, lecz żeby służyć $i$ dać swoje życie na okup za wielu (Mk 10,44); a od swych uczniów domagał się postawy i ducha służenia innym ${ }^{20}$. Apostołowie wczuli się dobrze w testament swego Mistrza, kiedy później, świadomi swojej misji, nazywali samych siebie sługami Chrystusa i Kościoła, sługami wszystkich ${ }^{21}$.

Kapłan ministerialny, będąc kontynuatorem misji Apostołów, staje się również sługą - sługą ludzkiego zbawienia. Jego funkcja wymaga od niego wielorakiej służby. Winien on służyć przede wszystkim Bogu jako Sprawcy zbawienia ludzkiego, a także Kościołowi jako nosicielowi i odbiorcy zbawczej mocy Boga, w Kościele zaś i poprzez Kościół każdemu człowiekowi. Analizując zagadnienie od strony funkcyjnej można by też powiedzieć, że kapłan służy Ludowi Bożemu swoim słowem (posługa Ewangelii), szafarstwem sakramentów św., sprawowaniem Eucharystii. Jego właściwa rola w kapłańskiej wspólnocie Ludu Bożego sprowadza się więc ostatecznie do służenia innym.

Nic też dziwnego, że myśl o służebnym charakterze kapłaństwa ministerialnego przewija się $\mathrm{w}$ wielu tekstach soborowych. II Sobór Watykański twierdzi m. in., że ,,prezbiterzy przez święcenia i misję, otrzymaną od biskupów, zostają wyniesieni do służenia Chrystusowi" (DK 1), stają się ,sługami Jezusa Chrystusa" (DK 2, 3, 5, 14 n.) i „ludzi” (DK 3, 4, 16; DB 30), są ,sługami słowa” (DK 4, 5, 13), „Eucharystii” (DK 5) i „Kościoła” (DB 28), ,służą powierzonym sobie ludziom i całemu Ludowi Bożemu” (DK 12; KK 28; DB 15), ,są narzędziami w służbie całego Ludu Bożego" (DK 12), „w służbie dla ludzkiego zbawienia” (DB 35). To mocne wyeksponowanie służebnego charakteru kapłaństwa hierarchicznego wiąże się z naciskiem, z jakim Sobór mówi o kapłańskiej godności dzieci Bożych. Skkoro bowiem ,wszyscy wierni stają się świętym i królewskim kapłaństwem, składają Bogu duchowe ofiary przez Jezusa Chrystusa i głoszą wspaniałe dzieła Tego, który ich wezwał z ciemności do przedziwnego swojego światła" (DK 2), to ich królewskie kapłaństwo domaga się, dla swej pełnej aktualizacji, posługi kapłana hierarchicznego. II Sobór Watykański myśl tę wyraża następująco: ,ażeby wierni zjednoczyli się w jedno ciało, w którym ,wszystkie członki nie mają tej samej czynności" (Rz 12, 4), ustanowił tenże Pan niektórych z nich sługami, aby posiadali w społeczności wiernych świętą władzę kapłańską (sacra Ordinis potestate pollerent) składania

20 Por. Mt 20, 26 n.; Mk 10, 43 n.

21 Por np. Rz 1, 1; 1 Kor 3, 5; 2 Kor 4, 5.

19 - Analecta Cracoviensia 
Ofiary i odpuszczania grzechów i aby w imieniu Chrystusa sprawowali publicznie, dla ludzi, urźąd kapłański” (DK 2).

Sakrament święceń, mocą którego niektórzy spośród wiernych upodobniają się do Chrystusa-Kapłana, wchodząc niejako w orbitę Jego jedynego i nieporównywalnego kapłaństwa, sprawia, że „kapłani” Nowego Testamentu uobecniają w zgromadzeniu wiernych wiecznotrwałe kapłaństwo Jezusa wraz z całym bogactwem obu jego zasadniczych funkcji: królewskiej i prorockiej. Wyświęcani są przecież po to, „aby głosić Ewangelię, być pasterzami wiernych i sprawować kult Boży. jako prawdziwi kapłani Nowego Testamentu" (KK 28). Dzięki ich posługiwaniu wierni nie tylko jednoczą się w jedno ciało, ale także aktualizują swe królewskie kapłaństwo. Uczestnicząc bowiem w sprawowanej przez kapłanów ministerialnych „Ofierze eucharystyczn'ej, tym źródle i zarazem szczycie całego życia chrześcijańskiego, składają Bogu boską Żertwę ofiarną, a wraz z Nią samych siebie [...]. Posileni zaś w świętej komunii Ciałem Chrystusowym, w konkretny sposób przedstawiają jedność Ludu Bożego, której stosownym znakiem i cudowną przyczyną jest ten Najświętszy Sakrament” (KK 11).

Szczytowe miejsce wśród wszystkich służb i zadań, jakie kapłani ministerialni pełnią w Ludzie Bożym, zajmuje posługa eucharystyczna. Słowa II Soboru Watykańskiego nie pozostawiają pod tym względem cienia wątpliwości: „W tajemnicy Ofiary eucharystycznej, w której kapłani wypełniają swój główny obowiązek, dokonuje się nieustannie dzieło naszego odkupienia" - stwierdza soborowy Dekret o posłudze i życiu kapłanów (nr 13), podkreślając na innym miejscu, że jednym z głównych zadań duszpasterza jest nauczanie wiernych, w jaki sposób mają oni „składać Bogu Ojcu w ofierze Mszy boską żertwę i z nią ofiarowywać swe życie" (DK 5). Konstytucja dogmatyczna o Kościele głosi, że „w sakramencie chleba eucharystycznego uprzytamnia się i dokonuje jedność wiernych, którzy stanowią jedno ciało w Chrystusie" (KK 3), akcentując, iż „w każdej wspólnocie ołtarza, przy świętej służbie biskupa, ofiaruje się symbol swej miłości i jedności Ciała Mistycznego, bez której nie może być zbawienia" (KK 26), oraz rozwijając myśl nadzwyczaj ważką, a mianowicie, że sam Chrystus tym wszystkim, „których wiąże ściśle z życiem i posłannictwem swoim, daje również udział w swej funkcji kapłańskiej dla sprawowania kultu duchowego, aby Bóg był wielbiony, a ludzie zbawiani. Toteż ludzie świeccy, jako poświęceni Chrystusowi i namaszczeni Duchem Swiętym, w przedziwny sposób są powołani i przygotowani do tego, aby rodziły się w nich zawsze coraz obfitsze owoce Ducha. Wszystkie bowiem ich uczynki, modlitwy i apostolskie przedsięwzięcia, życie małżeńskie i rodzinne, codzienna praca, wypoczynek ducha i ciała, jeśli odbywa ją się w Duchu, a nawet utra- 
pienia życia, jeśli cierpliwie są znoszone, stają się duchowymi ofiarami, miłymi Bogu przez Jezusa Chrystusa (por. 1 P 2, 5); ofiary te składane są zbożnie Ojcu w eucharystycznym obrzędzie wraz z ofiarą Ciała Pańskiego" (KK 34). Ofiara eucharystyczna ukazuje się w tym świetle nie tylko jako źródło i szczyt życia chrześcijańskiego, ale też jako „ośrodek zgromadzenia wiernych, któremu przewodniczy prezbiter" (DK 5). Nazywana przez Sobór „,sakramentem miłosierdzia”, „znakiem jedności”, „węzłem miłości" (KL 47) Eucharystia jest przecież tym szczególnym momentem i miejscem, w którym spotykają się ze sobą, a zarazem i aktualizują w składaniu jednej i tej samej Bosko-ludzkiej żertwy ofiarnej kapłaństwo królewskie wiernych z urzędowym kapłaństwem Kościoła. Ona więc też, siłą faktu, stanowi centrum życia i posługi kapłana ministerialnégo.

Wszystkie powyższe spostrzeżenia i uwagi nabiorą większej wymowy, jeżeli się przeanalizuje znamiona, jakie - zdaniem II Soboru Watykańskiego - winny cechować kapłana katölickiego.

\section{ZNAMIONA CHARAKTERYZUJACE KAPEANA MINISTERIALNEGO}

Oparte na doktrynie II Soboru Watykańskiego, bądź też wynikające z niej wprost znamiona kapłana hierarchicznego wiążą się jak najściślej $\mathrm{z}$ tematem niniejszego opracowania; wskazują bowiem jeżeli nie wprost (pozytywnie), to przynajmniej ubocznie (w sposób negatywny) na znaki powołania. Gdyby ich zabrakło u człowieka przygotowującego się do przyjęcia święceń, można by nie bez racji powątpiewać, czy zamierza on wkroczyć na właściwą drogę życia, chociaż samo ich posiadanie nie świadczy chyba jeszcze, samo przez się, o istnieniu autentycznego powołania Bożego. Przypatrzmy się zatem pokrótce poszczególnym znamionom specyfikującym kapłana ministerialnego.

1. Zmysł transcendencji. Na pierwsze miejsce wśród cech specyfikujących kapłana wysuwa się zmysł transcendencji. Kapłan bowiem uobecnia sobą w zgromadźeniu wiernych samego Chrystusa. Fakt ten akcentują nie tylko liczne teksty II Soboru Watykańskiego, ale także posoborowe dokumenty kościelne. Te ostatnie precyzując myśl soborową ${ }^{22}$ o poczwórnej, narastającej ciągle obecności Chrystusa w zgromadzeniu liturgicznym, stwierdzają, że jest On osobiście obecny najpierw we wspólnocie wiernych, którzy się zebrali w Jego Imię, następnie w swoim Słowie czytanym i wyjaśnianym w Kościele, dalej - a o to nam chodzi szczególnie w tym miejscu - w osobie kapłana, by wreszcie, jakby na samym szczycie, zjawić się pod postaciami eưcharysty-

${ }_{22}$ Por. KL 7. 
cznymi ${ }^{23}$. W zestawieniu takim kapłan uobecnia sobą Chrystusa bardziej aniżeli wspólnota wiernych zgromadzonych na liturgię, a także bardziej aniżeli odczytywane.w trakcie zgromadzenia Słow.o Boże; jedynie Eucharystia przewyższa sobą obecność Chrystusa zjawiającego się podczas liturgii w osobie kapłana. Fakt ten, wiele mówiący sam przez się, pociąga za sobą szereg konsekwencji praktycznych. O ile bowiem kapłan uobecnia - można by powiedzieć: ontycznie - Chrystusa, powinien Go też uobecniać egzystencjalnie: wczuwać się głęboko i przeżywać faktycznie wszystko, co się wiąże z tą rolą, występować wobec ludzi jako ten, który wiąże niebo z ziemią, a ziemię z niebem.

II Sobór Watykański ûwypukla tę myśl m.in. wtedy, gdy podkreśla, że kapłani ,poświęceni Bogu nowym sposobem w momencie przyjęcia święceń, stają się żywymi narzędziami Chrystusa Wiecznego Kapłana, aby mogli kontynuować przez wieki Jego przedziwne dzieło, które skutecznością z wysoka odnowiło cały rodzaj ludzki. Ponieważ więc każdy kapłan na swój sposób zastępuje osobę samego Chrystusa (ipsius Christi personam gerat), obdarzony jest też szczególną łaską, aby służąc powierzonym sobie ludziom i całemu Ludowi Bożemu, mógł łatwiej dążyć do doskonałości Tego, którego reprezentuje (cuius partes sustinet)" (DK 12).

Do tej samej myśli nawiązuje soborowy Dekret o formacji kapłańskiej, kiedy poleca alumnom przygotowującym się do święceń, aby „nauczyli się żyć w zażyłej i nieustannej łączności z Ojcem przez Syna Jego Jezusa Chrystusa w Duchu Swiętym. Mając przez święcenia upodobnić się do Chrystusa-Kapłana, niech także trybem całego życia przyzwyczajają się przylgnąć do Niego najserdeczniej jako przyjaciele. [...] Niech nauczą się szukać Chrystusa w wiernym rozważaniu słowa Bożego, w czynnym uczestnictwie w świętych tajemnicach Kościoła, a przede wszystkim w Eucharystii i w modlitwie brewiarzowej; niech Go szukają w biskupie, który ich posyła, i w ludziach, do których są posyłani, szczególnie w biednych, maluczkich, chorych, w grzesznikach i niewierzących" (DFK 8).

Brak zmysłu transcendencji, czyli tego głębokiego odczuwania i przeżywania spraw Bożych, nastawienia na Tajemnicę i świadomości, że jest się rzecznikiem, głosicielem, przedstawicielem i - co najważniejsze - uobecnieniem Tajemnicy, wskazywałby, w tym ujęciu, na nieprzydatność danego kandydata do stanu duchownego.

2. Zdecydowána wola służenia ludziom. O służebnym charakterze kapłaństwa ministerialnego powiedzieliśmy już wyżej

${ }_{23}$ Por. Instrukcja o kulcie tajemnicy eucharystycznej (z $25 \mathrm{~V}$ 1967), wyd. Sw. Kongregacja Obrzędów, 9; Rituale romanum. De sacra communione et de cultu mysterii eucharistici extra missam, Vaticani 1973, praenotanda generalia 6. 
stosunkowo dużo. II Sobór Watykański precyzując jednak teorię i chąc' ją wprowadzić w życie podaje szereg wskazań praktycznych, które przenoszą niejako służebność z płaszczyzny ontycznej w egzystencjalną. Ze wskazań tych wynika, że kapłan, który z natury swego powołania jest sługą Chrystusa, Kościoła i wszystkich spraw Bożych, powinien faktycznie się odznaczać zdecydowaną wolą służenia. Oto niektóre z bardziej wymownych wskazań Soboru w tym względzie:

„Prezbiterzy zatem tak winni przewodniczyć, by nie szukając swego, lecz tego, co należy do Jezusa Chrystusa, współpracowali z wiernymi świeckimi i zachowywali się wśród nich na wzór Mistrza, który między lud ,nie przyszedł, aby mu służono, ale aby służyć "i duszę swą oddać na okup za wielu" (Mt 20,28). Niech prezbiterzy szczerze uznają i popierają godność świeckich i właściwy im udział w posłannictwie Kościoła. Niech także szczerze szanują słuszną wolność, która przysługuje wszystkim w ziemskim państwie. Niech chętnie słuchają świeckich, rozpatrując po bratersku ich pragnienia i uznając ich doświadczenie i kompetencję w różnych dziedzinach ludzkiego działania, by razem z nimi rozpoznać znaki czasów. Badając duchy, czy pochodzą od Boga, niech w duchu wiary odkrywają różnorodne charyzmaty świeckich, zarówno małe jak i wielkie, niech je $\mathrm{z}$ radością uznają, $\mathrm{z}$ troskliwością popierają. [...] Niech też $\mathrm{z}$ zaufaniem powierzają świeckim zadania $\mathrm{w}$ służbie Kościoła, zostawiając im swobodę i pole do działania, owszem, odpowiednio zachęcając ich, by przystępowali do pracy także z własnej inicjatywy" (DK 9).

Wola służenia ludziom ma się takżè przejawiać, zdaniem II Soboru Watykańskiego, w życiu i postawie kandydatów do kapłaństwa: „Alumni winni doskonale rozumieć, że nie są przeznaczeni do panowania i do zaszczytów, ale że poświęcają się całkowicie na służbę Bogu oraz posługę duszpasterską" (DFK 9). Jest więc ona niewątpliwie jednym ze znamion autentycznego powołania kapłańskiego.

3. Umiłowanie Eucharystii. Z zacytowanych nieco wyżej wypowiedzi II Soboru Watykańskiego wynika, że Ofiara eucharystyczna jest tym szczególnym wydarzeniem w życiu Kościoła, w którym kapłańska' posługa we wspólnocie Ludu Bożego osiąga swą pełnię. Elementem integralnym liturgii eucharystycznej jest natomiast dar całopalny, składany Bogu przez kapłana ministerialnego i wszystkich obecnych - z samych siebie. „Tak więc, kiedy prezbiterzy łączą się z czynnością Chrystusa Kapłana, siebie całych codziennie ofiarują Bogu" stwierdza Sobór (DK 13), dodając na innym miejscu, że Kościół troszczy się bardzo o to, by chrześcijanie „ofiarując niepokalaną hostię nie tylko przez ręce kapłana, lecz także razem z nim, uczyli się samych siebie składać w ofierze" (KL 48). Na tej ofierze ze siebie fakty- 
cznie bowiem polega i w niej się przejawia królewskie kapłaństwo wszystkich ochrzczonych (zarówno przedstawicieli hierarchii, jak i wiernych świeckich). Uzuṕpłniając niejako myśl powyższą Sobór jeszcze dodaje: „By zaś sprawowanie Eucharystii było prawdziwe i pełne, musi prowadzić zarówno do różnych dzieł miłości i wzajemnej pomocy, jak i do akcji misyjnej, a także do różnych form świadectwa chrześcijańskiego" (DK 6). Na pierwsze miejsce w Tajemnicy eucharystycznej wysuwa się zatem składanie podwójnej ofiary: kapłan ministerialny oraz wierni świeccy ,składają Bogu boską Żertwę ofiarną, a wraz z Nią samych siebie" (KK 11).

$\mathrm{Z}$ tą podwójną ofiarą wiąże się z kolei nierozdzielnie Komunia eucharystyczna. Albowiem „wierni naznaczeni już znakiem chrzț świętego i bierzmowania, włączają się całkowicie w Ciało Chrystusowe przez przyjęcie Eucharystii” (DK 5), a posilając się Nią ,,w konkretny sposób przedstawiają jedność Ludu Bożego, której stosownym znakiem i cudowną przyczyną jest ten Najświętszy Sakrament" (KK 11).

Posoborowe dokumenty kościelne zwracają ponadto uwagę na wielką rolę 'adoracji przed Najśw. Sakramentem dla życia wszystkich chrześcijan. Przebywający przy Chrystusie, którego obecność wywodzi się z Ofiary i zmierza do Komunii św., ludzie ,wylewają przed Nim swe serce za siebie i wszystkich swoich, modlą się o pokój i zbawienie świata. Oddając w ofierze z Chrystusem całe swe życie Ojcu w Duchu Swiętym, czerpią z tego przedziwnego obcowania wzrost $\mathrm{w}$ wierze, nadziei i miłości. Tak to podsycają owe właściwe dyspozycje, by dzięki nim mogli z należytą pobożnością obchodzić pamiątkę Pańską i przyjmować często ów chleb dany nam przez Ojca" ${ }^{24}$.

To wspólne dla wszystkich chrześcijan umiłowanie Eucharystii stanowiącej samo centrum życia i posługi kapłana ministerialnego winno się przejawiać w sposób szczególny u człowieka przygotowującego się do przyjęcia święceń. Mówią o tym niedwuznacznie - rozwijając każdy z trzech wymienionych przejawów pobożności eucharystycznej - posoborowe instrukcje dotyczące formacji liturgicznej w seminariach duchownych ${ }^{25}$.

4. Ś wiadoma troska o jedność. Z Eucharystią nazwaną przez II Sobór Watykański ,znakiem i cudowną przyczyną” jedności Ludu Bożego wiąże się ściśle następna cecha znamionująca kapłana ministerialnego. Jest nią mianowicie nieustanne dążenie do jedności narażonej wciąż na niebezpieczeństwa wskutek grzechu tkwiącego w na-

${ }^{24}$ Instrukcja, jw., 50.

25 Por. Instrukcja o liturgicznym wychowaniu alumnów (z 25 XII 1965), wyd. Sw. Kongregacja dla Seminariów i Uniwersytetów, $23 \mathrm{nn}$.; Instructio de institutione liturgica in seminariis (3 VI 1979), ed. S. Congregatio pro Institutione Catholica, 22 nn. (w: „Notitiae” 15, 1979, 534 nn.). 
turze ludzkiej. Zrozumiałą stąd jest rzeczą, że II Sobór Watykański, który troskę o zachowanie i umocnienie jedności wśród chrześcijan oraz w całym Ludzie Bożym uznał za jedno ze swych podstawowych zadań ${ }^{26}$, a także nie zawahał się nazwać Kościoła ,widzialnym sakramentem owej zbawczej jedności" (KK 9), ukazał w swych dokumentach kapłaństwo ministerialne jako czynnik dynamizujący oraz warunkujący w pewnej mierze tę powszechną jedność. Ta jednocząca - z samej swej natury - funkcja kapłana wymaga od niego odpowiedniej postawy życiowej. Sam Sobór ujmuje to zagadnienie następująco:

„Są na koniec prezbiterzy postawieni wśród świeckich, by prowadzili wszystkich do zjednoczenia w miłości, ,miłością braterską nawzajem się miłując, w okazywaniu czci jedni drugich uprzedzając" (Rz 12, 10). Ich przeto zadaniem jest w taki sposób godzić różne poglądy, aby nikt w społeczności wiernych nie czuł się obcym” (DK 9). A ,ponieważ rodzaj ludzki zespala się dziś coraz bardziej w jedność obywatelską ekonomiczną i społeczną, tym bardziej przeto słuszną jest rzeczą, aby kapłani, połączywszy pod przewodnictwem biskupów i papieża swe troski i wysiłki, usuwali wszelkie powody rozproszenia, tak iżby cały rodzaj ludzki doprowadzony był do jedności rodziny Bożej” (KK 28).

Swiadome dążenie do jedności, a zwłaszcza praca nad ciągłym jej pogłębianiem nie są rzeczą łatwą. Ważna tu jest pomoc wzajemna, współpraca księży między sobą, ważne też jest odpowiednie przygotowanie. W związku z tym Sobór kładzie wielki nacisk na ,najściślejsze braterstwo sakramentalne", wynikające ze wspólnych dla wszystkich kapłanów święceń i ze wspólnej posługi pasterskiej. Wszyscy bowiem zostali posłani, by ,współpracować w tym samym dziele”, wszyscy także „dążą do jednego, mianowicie do budowania Ciała Chrystusowego" (DK 8). Ta wspólnota zadań i celów sprawia, że poszczególni prezbiterzy ,jednoczą się ze swymi współbraćmi węzłem miłości, modlitwy i wszelkiej współpracy, dzięki czemu ujawnia șę ta jedność, w której Chrystus chciał, by Jego wyznawcy byli całkowicie zjednoczeni" (DK 8).

Współpraca księży ze sobą i z biskupem trudna byłaby jednak do osiągnięcia, gdyby jej nie poprzedziła odpowiednia formacja seminaryjna. W związku z tym odnośny Dekret soborowy stawia jasne i zdecydowane żądania, które można śmiało uznać za znamiona autentycznego powołania kapłańskiego: „Niech alumni tak będą przepojeni tajemnica Kościoła, przez ten święty Sobór szczególnie oświetloną, aby przejęci pokorną i synowską miłością do Namiestnika Chrystusowego, a także, po święceniach kapłańskich, przywiązani do własnego biskupa jako wier-

${ }_{26}$ Por. DE 1 n.; KDK 44, 92. 
ni współpracownicy oraz współtowarzysze braci w pracy, dawali świadectwo owej jedności, która ludzi do Chrystusa przyciąga" (DFK 9).

5. D y spozycyjuość. Następną cechą charakteryzującą kapłaństwo ministerialne jest jego dyspozycyjność, czyli - jak ją określa pap. Jan Paweł II - ,pokorna gotowość odbierania darów Ducha Swiętego i obdarowywania innych owocami miłości i pokoju - obdarowywania ich tą pewnością wiary, z której płynie głębokie poczucie sensu ludzkiego bytowania oraz umiejętność wprowadzania ładu moralnego w życie osób i ludzkich środowisk". Wspomniana dyspozycyjność opiera się z jednej strony na różnorodności funkcji i posług w Kościele, zmierzających ostatecznie do tego samego celu, z drugiej zaś na służebnym charakterze kapłaństwa katolickiego. Przejawia się natomiast w otwarciu kapłana na „głos” Boży i potrzeby Kościoła. Będąc sługą Chrystusa i wiernych kapłan ministerialny nie może w pełni sobą dysponować. Jego życie nie należy już całkowicie do niego, stało się bowiem - na skutek podjętych dobrowolnie w momencie święceń zobowiązań - własnością Ludu Bożego. Dlatego też mając na uwadze ten właśnie przymiot osobowości kapłańskiej pap. Jan Paweł II pisze dalej: „,Kapłaństwo domaga się szczególnej niepodzielności życia i służby. Ta właśnie niepodzielność stanowi najgłębiej o naszej kapłańskiej tożsamości. W niej wyraża się równocześnie nasza wielka godność - i proporcjonalna do tej godności «dyspozycyjność»" ${ }^{27}$.

$\mathrm{Na}$ jakąś fundamentalną dyspozycyjność kapłaństwa ministerialnego wskazywał zresztą II Sobór Watykański, gdy stwierdzał, że „dar duchowy, otrzymany przez prezbiterów w święceniach, przygotowuje ich nie do jakiejś ograniczonej i zacieśnionej misji, lecz do najszerszej i powszechnej misji zbawienia aż po krańce ziemi; [...] Chrystusowe bowiem kapłaństwo, którego prezbiterzy stali się prawdziwie uczestnikami, niechybnie skierowane jest do wszystkich ludów i do wszystkich czasów i nie jest skrępowane żadnymi ograniczeniami krwi narodu lub wieku. [...] Stąd też niech prezbiterzy tych diecezji, które są obdarzone większą ilością powołań, z ochotą okazują gotowość - za pozwoleniem lub zachętą swego ordynariusza - pełnienia swej posługi w krajach, na misjach lub w dziełach cierpiących na brak duchowieństwa" (DK 10).

Kościół nie twierdził nigdy, że dyspozycyjność jest rzeczą łatwą. Wymaga ona bowiem niejednej ofiary, a niekiedy nawet wiąże się $\mathrm{z}$ darem całopalnym ze siebie, stwarzając tym samym dla kapłana ministerialnego wiele dogodnych okazji do aktualizowania swego królewskie-

${ }^{27}$ List Ojca Swiętego Jana Pawła II do wszystkich kapłanów Kościoła na Wielki Czwartek 1979 roku, 4. 
go kapłaństwa. Prowadzi też, siłą faktu, do Eucharystii i pozwala kapłanowi ministerialnemu lepiej ją przeżywać. Podjęcie się jakiejkolwiek nowej posługi w Ludzie Bożym, zleconej przez prawowitą władzę, staje się przecież niejednokrotnie tym szczególnym wydarzeniem, w trakcie którego zespalają się ze sobą ściśle, podobnie jak to ma miejsce w Eucharystii, kapłaństwo ministerialne i wspólnotowe. Zespolenie to różni się jednak od eucharystycznego o tyle, że w Ofierze Mszy św. uwidacznia się ono przede wszystkim, choć nie wyłącznie, we wspólnym składaniu kapłańskiej ofiary ze siebie przez wiernych uczestniczących w Liturgii i jednoczeniu jej - poprzez posługę kapłana-duszpasterza z kapłańską ofiarą Syna Bożego; w trakcie podejmowania jakiejś nowej posługi natomiast (zmiany stanowiska, miejsca lub rodzaju -pracy itp.) miejscem zespolenia jest samo wnętrze kapłana, który mocą swej osobistej, kapłańskiej ofiary, „zakonsekrowanej” decyzją lub posługą biskupa, osiąga coraz pełniejszy i głębszy udział w samym kapłaństwie Chrystusa.

Do tak pojętej dyspozycyjności, a więc i gotowości podejmowania różnorodnych ,zadań sług Bożych" (KK 41) powinni się przygotowywać w latach studiów seminaryjnych kandydaci do kapłaństwa. Owocem wszelkich starań podejmowanych w tej dziedzinie ma być „,wewnętrzna podatność alumnów na poddawanie się władzy przełożonych z głębokiego przekonania, czyli z wymogów sumienia i z pobudek nadprzyrodzonych" (DFK 11) ${ }^{28}$. Oficjalną zaś pomocą w wyrabianiu pełnej dyspozycyjności mają być, z woli samego Kościoła, podejmowane przez kandydatów do kapłaństwa oficjalne posługi (lektorat, akolitat) oraz przyjmowane przez nich święcenia; wszystkie te wydarzenia pozwalają bowiem alumnom aktualizować coraz bardziej swe królewskie kapłaństwo, a tym samym upodabniać się ściślej do Chrystusa - jedynego i wiekuistego Kapłana.

6. Umiejętność zachowywania właściwego dys t a n su. Cechę, o której mowa, można by też nazwać duchowym odłączeniem, wewnętrzną izolacją, ustosunkowywaniem się do spraw i przebywaniem wśród ludzi „,po kapłańsku”. Chodzi w niej mianowicie o umiejętność łączenia ze sobą dwóch pozornie wykluczających się postaw: bycia z ludźmi, a więc $w$ świecie i na świecie, ale nie ,ze świata" ( $\mathrm{J}$ 17, 16). Akcentuje ją mocno pap. Jan Paweł II, gdy w liście adresowanym do kapłanów pisze m.in.: „Nasza praca duszpasterska domaga się tego, abyśmy byli blisko ludzi i wszystkich ludzkich spraw czy to będą sprawy osobiste, czy rodzinne, czy społeczne - ale byśmy

${ }^{28}$ Por. DFK 9. 
byli blisko tych wszystkich spraw „po kapłańsku”. Wtedy tylko - w kręgu tych wszystkich spraw - jesteśmy sobą" ${ }^{29}$.

Aspekt pierwszy zagadnienia - to żywa, przybierająca stopniowo na sile w życiu i postawie kapłana świadomość ścisłej więzi ze wspólnotą. Świadomość ta powinna - zgodnie z doktryną II Soboru Watykańskiego - przenikać całe życie kapłańskie i być motorem wielu konkretnych poczynań. „Ze wszystkimi bowiem odrodzonymi w wodzie chrztu prezbiterzy są braćmi wśród braci, jako członkowie jednego i tego samego Ciała Chrystusowego, którego budowanie zlecone jest wszystkim” (DK 9). Chociaż więc zostali „wzięci z ludzi i postawieni dla ludzi w tych sprawach, które wiodą do Boga, aby ofiarowali dary i ofiary za grzechy, żyją z innymi ludźmi jako z braćmi" (DK 3) i chociaż „z racji sakramentu kapłaństwa wykonują wśród Ludu i dla Ludu Bożego bardzo wzniosłą i konieczną funkcję ojca i nauczyciela, wspólnie jednak ze wszystkimi wiernymi są uczniami Pana, uczestnikami Jego Królestwa dzięki łasce powołującego Boga" (DK 9).

Aspekt drugi II Sobór Watykański ujmuje następująco: „Prezbiterzy Nowego Testamentu przez swe powołanie i wyświęcenie zostają wydzieleni w jakiś sposób z Ludu Bożego, jednak nie w celu odłączenia ich od niego lub od jakiegokolwiek człowieka, lecz by całkowicie poświęcili się dziełu, do którego powołuje ich Pan. Nie mogliby być sługami Chrystusa, gdyby nie byli świadkami i szafarzami innego życia niż ziemskie; lecz nie potrafiliby też służyć ludziom, gdyby pozostali obcymi w stosunku do ich życia i warunków. Sama ich posługa domaga się w szczególny sposób, by nie upodabniali się do tego świata; równocześnie jednak wymaga, by na tym świecie żyli wśród ludzi i jako dobrzy pasterze znali swe owce i starali się doprowadzić także te, które nie są z ich owczarni, by i one usłyszały głos Chrystusa i aby nastała jedna owczarnia i jeden Pasterz" (DK 3).

$\mathrm{Z}$ zestawienia obu tych aspektów wynika, że kapłan ministerialny, zespolony wieloma węzłami z kapłańską wspólnotą Ludu Bożego, nie może być, mimo wszystko, z tą wspólnotą ,zmieszany". Jeżeli ma praw̌ dziwie, „po kapłańsku” służyć tej wspólnocie, powinien posiąść zdolność zachowywania właściwego dystansu w odniesieniu do spraw i ludzi, osób i rzeczy. Jego misja w świecie wymaga dla swej pełnej realizacji, by zachował on w swym życiu postawę duchowej izolacji, wewnętrznego odłączenia od pozostałych członków wspólnoty kościelnej. Odosobnienie, o które chodzi, ma oczywiście bardziej teologiczny, aniżeli socjologiczny charakter i wyraża się w dogłębnym skoncentrowaniu na wiernym wypełnianiu swego posłannictwa.

29-30 Liśt Ojca Swiętego Jana Pawła II do wszystkich kapłanów Kościoła na Wielki Czwartek 1979 roku, 7. 
Nie potrzeba oczywiście dodawać, że oba aspekty omawianego tu „odłączenia”, jako nieodzowne w życiu i "posłudze kapłana, muszą znaleźć właściwe sobie miejsce $\mathrm{w}$ formacji seminaryjnej przyszłych duszpasterzy. Kandydaci do kapłaństwa winni zatem uświadamiać sobie przede wszystkim to (i przejawiać tę świadomość całą swą postawą), że chociaż chwilowo i pozornie oderwani są od ludzi, pozostają jednak z ními w ścisłej, nieprzerwanej wewnętrznej łączności, którą pogłębiają podejmując się dobrowolnie odpowiednich posług i przyjmując kolejne święcenia przeznaczające ich do coraz to szerszej służby Ludowi Bożemu. Z drugiej strony obowiązkiem wszystkich alumnów jest wyrabianie w sobie umiejętności zachowywania właściwego dystansu wobec spraw i ludzi; jakikolwiek brak w tym względzie może się okazać katastrofalny w ich później̦szym życiu. Dlatego też II Sobór Watykański z naciskiem poleca: „Cały program Seminarium, przepojony zamiłowaniem do pobożności i milczenia oraz troską o wzjemną pomoc, należy tak ułożyć, aby stanowił już poniekąd zapoczątkowanie przyszłego życia, jakie kapłan ma prowadzić" (DFK 11).

7. Autentyzm życia. Na ostatnim miejscu wypada omówić znamię, które zespala w sobie, w pewnym stopniu, wszystkie inne. Jest nim autentyzm życia kapłańskiego. Jego rolę uwypukla pap. Jan $\mathrm{Pa}-$ weł II, kiedy pisze w liście skierowanym do kapłanów: „Osobowość kapłańska musi być dla drugich wyraźnym i przejrzystym znakiem i drogowskazem. [...] Ludzie, spośród których iesteśmy wzięci i dla których jesteśmy ustanowieni, chcą nade wszystko znajidować w nas taki znak i taki drogowskaz. I mają do tego prawo. Może nam się czasem wydawać, że tego nie chcą. Że chcą, abyśmy byli we wszystkim „tacy sami". Czasem wręcz zdaje się, że tego od nas się domagają. Tutaj wszakże potrzebny jest głęboki ,zmysł wiary” oraz „dar rozeznania”. Bardzo łatwo bowiem ulec pozorom i paść ofiarą zasadniczego złudzenia". Jan Paweł II dodaje jeszcze, że ,ostatecznie zawsze potrzebny ludziom okaże się tylko kapłan świadomy pełnego sensu swego kapłaństwa: kapłan, który głęboko wierzy, który odważnie wyznaje, który żarliwie się modli, który z całym przekonaniem naucza, który służy, który wdraża w swe życie program ośmiu błogosławieństw, który umie bezinteresownie miłować, który jest bliski wszystkim - a w szczególności najbardziej potrzebującym" ${ }^{30}$.

W słowach Jana Pawła II dostrzec można jakby echo, a zarazem nowe odczytanie wypowiedzi II Soboru Watykańskiego, który stwierdziwszy krótko, że „prezbiterzy osiągną świętość w sposób im właściwy, wypełniając szczerze i niezmordowanie swe obowiązki w Duchu Chrystusowym" (DK 13), omawia poszczególne, środki i pomoce uła- 
twiające kapłanom dążenie do świętości, a tym samym i autentyzm życia. Na pierwszym miejscu Sobór wymienia codzienne, godne sprawowanie Najśw. Ofiary, zachęcając kapłanów, by „naśladowali to, co sprawują, bo obchodząc tajemnicę śmierci Pańskiej, winni się starać przez umartwienie uwolnić swe członki od wad i pożądliwości" (DK 13). Prawdziwa miłość duszpasterska wypływa zresztą - zdaniem Soboru ,głównie z Ofiary eucharystycznej, która dlatego pozostaje ośrodkiem i korzeniem całego życia prezbitera, tak że to, co dzieje się na ołtarzu ofiarnym, dusza kapłańska stara się odtworzyć w sobie" (DK 14). Takiej postawy z kolei nie można osiągnąc bez modlitwy, która — jak to podkreśla pap. Jan Paweł II - „wyznacza istotny styl życia kapłańskiego" ${ }^{31}$. Chodzi tu przede wszystkim o codzienną rozmowę „z Chrystusem Panem w nawiedzaniu i osobistym kulcie Najświętszej Eucharystii" (DK 18), o regularne odprawianie ćwiczeń duchownych, zwłaszcza zaś o modlitwę myślną i inne dowolnie wybrane formy modlitw, o regularne i owocne przyjmowanie salkramentów św., o kierownictwo duchowe, a także o zgłębianie się w teksty Pisma św. i dzieł mistrzów życia wewnętrznego. Akcentując rolę modlitwy brewiarzowej w życiu kapłana II Sobór Watykański zaznacza, że „w odmawianiu Świętego Oficjum użyczają prezbiterzy głosu Kościołowi, trwającemu na modlitwie w imieniu całego rodzaju ludzkiego, razem z Chrystusem, który „żyje zawsze, aby się wstawiać za nami” (Hbr 7, 25)" (DK 13). Wszystkie te formy spotkań i rozmowy z Bogiem mają - zdaniem II Soboru Watykańskiego - dopomóc kapłanom w tym, by z dnia na dzień stawali się „,coraz doskonalszymi uczniami Pana” (DK 13).

Z niekłamanym bólem pap. Jan Paweł II stwierdza, że „może za wiele $\mathrm{w}$ ostatnich czasach - przynajmniej w niektórych środowiskach dyskutowano o kapłaństwie, o ,tożsamości” kapłana, o jego znaczeniu w świecie współczesnym itp., a za mało się modlono. Za mało starano się poprzez modlitwę wcielać w życie samo kapłaństwo, urzeczywistniać jego autentyczny dynamizm ewangeliczny, potwierdzać kapłańską tożsamośc" ${ }^{32}$. Tymczasem właśnie modlitwa, jak najszerzej pojęta, jest nieodzowna w życiu kapłana. Ona to pomaga odnajdywać to światło, ,które nas prowadziło od początku powołania kapłańskiego i stale prowadzi, choć czasem zdaje się ginąć w mroku. Modlitwa pozwala nam stale się nawracać, trwać w stanie nieustannego dążenia do Boga, które jest nieodzowne, jeśli mamy innych do Niego prowadzić. Modlitwa pomaga nam wierzyć, ufać i miłować nawet wówczas, gdy nasza ludzka słabość nam w tym przeszkađza" ${ }^{33}$.

Zarówno II Sobór Watykański, jak i pap. Jan Paweł II podkreślają 
ponadto rolę wiedzy oraz konieczność ustawicznego dokształcania się kapłanów. Zapoczątkowany $\mathrm{w}$ seminarium proces wykształcenia trzeba „,przedłużyć na całe życie” - stwierdza Jan Paweł II dodając, że głębia i autentyzm kapłańskiego życia wewnętrznego muszą ,znajdować oparcie w wytrwałym studium" ${ }^{34}$. Słowa te są jedynie komentarzem do zaleceń Kościoła, który poleca kapłanom, aby „byli dojrzali w wiedzy” i aby ich nauka była „duchowym lekarstwem dla ludu Bożego" 35. Taką pogłębioną wiedzę teologiczną, wymagającą nieustannej konfrontacji z doświadczeniami świata współczesnego, czerpie się - jak podkreśla to Sobór — ,z czytania i rozważania Pisma świętego, ale również owocnie zasila się studiowaniem pism Ojców i Doktorów Kościoła oraz innych dokumentów Tradycji”, a także zasięganiem rady ,najlepszych i uznanych pisarzy teologicznych" (DK 19).

Nie potrzeba oczywiście dodawać, że te wszystkie cechy wskazujące i warunkujące zarazem autentyzm życia, powinny się pojawiać, przynajmniej $\mathrm{w}$ stanie zaczątkowym, u kandydatów przygotowujących się do przyjęcia święceń kapłańskich. Jak zauważa bowiem II Sobór Watykański, ,głosu wołającego Pana nie należy żadną miarą tak oczekiwać, jak gdyby miał on dojść do uszu przyszłego prezbitera w jakiś nadzwyczajny sposób. Należy go bowiem pojąć i osądzić raczej ze znaków, przez -które wola Boża staje się wiadoma na co dzień roztropnym chrześcijanom. Znaki te winny być przez prezbiterów pilnie rozważane" (DK 11) ${ }^{36}$. Powinny się też w jakiejś mierze ujawniać w postawie i postępowaniu kandydatów do kapłaństwa.

Ujmując rzecz innymi słowy, można by powiedzieć, że znamiona cechujące kapłana Chrystusowego winny dojśá do głosu w procesie formacyjnym przyszłych kapłanów. Całe kształtowanie alumnów ma zatem zmierzać do tego, by „na wzór Pana naszego Jezusa Chrystusa, Nauczyciela, Kapłana i Pasterza wyrabiali się oni na prawdziwych duszpasterzy. Niech więc przygotowują się do posługi słowa: aby objawione słowo Boże coraz lepiej rozumieli, przez rozmyślanie posiedli, a mową i obyczajami wyrażali; do posługi kultowej oraz uświęcania: aby modląc się i spełniając święte czynności liturgiczne wykonywali dzieło zbawienia przez Ofiarę eucharystyczną i sakramenty; do posługi pa-

${ }^{35}$ DK 19. II Sobór Watykański cystuje tu słowa wypowiadane przez biskupa podiczas udzielania święceń kapłańskich.

${ }^{36}$ II Sobór Watykański przytacza tutaj w przypisie wypowiedź papieża Pawła VI z 5 V 19i65: „Głos wołającego Boga wyraża się na dwa różne sposoby, cudowne i zbieżne: jeden wewnętrzny, głos łaski, Ducha Swiętego, ten niewypowiedziany urok wewnętrzny, wywołany w niezbadanych głębinach duszy ludzkiej przez potężny i ,milczący głos" Pana; inny, zewnętrzny, ludzki, odczuwalny, społeczny, prawny, konkretny, głos kompetentnego sługi Słowa Bożego, głos Apostoła, głos Hierarchlii, niezbędny instrument, ustanowiony i chciany przez Chrystusa, jako środek, którego zadaniem jest przełożyé na język zrozumiały orędzie Słowa i Bożego przykazania". 
sterskiej: aby umieli ukazywać ludziom Chrystusa, który nie przyszedt, aby mu stużono, ale aby stużyć i oddać duszę swoja na okup za wielu (Mk 10, 45; por. J 13, 12-17), i aby stawszy się sługami wszystkich, wielu pozysskali"' (DFK 4).

\section{PORTÉE DE LA CONCEPTION DU SACERDOCE ELADOREE PAR LE CONCILE VATICAN II POUR LA SPECIFICATION DES SIGNES DE LA VOCATION}

Rés u mé

C'est évident, que le Concile Vatican II a causé beaucoup de changements dans la vie et le ministère des prêtres. On parlait souvent, après le Concile, sur la vraie crise d'identité du prêthe qui a perdu - déjà avant le Concile - beaucoup de ses fonctions, laïques et sacrales et qui était, comme le parfois nommait, „L'homme sans métier”. Le prêtre, après le Concile, n'est pas plus l'homme qui se trouve au-dessus des laícs et qui est entouré par la vénération univ́erselle des fidèles. Il doit être le frère parmi des frères et le pasteur qui donne sa vie pour ses brebis. Il se trouve parmi, et pas au-dessus des fidèles, quoique tout cela ne lui permet pas de se mêler aux laïcs. Sa vie et ses fonctions se deviennent encore plus difficiles qu'elles étaient auparavant.

$\mathrm{Si}$ le Concile Vatican II a approfondi cette crise d'identité du prêtre, il en a fait par doctrine sur l'Eglise, par celle sur le salut et sur le sacerdoce hiérarchique et royal des fidèles. En décrivant l'Eglise Vatican II a souligné une véritable égalité qui règne entre tous, "même si certains, par volonté du Christ, sont institués docteurs, dispensateurs des mystères et pasteurs pour le bien des autres" (LG 32). Quant au salut qui était présenté avant le Concile une réalité descendente d'en haut et par intermédiaire de hiérarchie ecclésiastique distribuée aux fidèles, Vatican II a présenté un enseignement bien précis en le montrant comme une réalité qui est présente dans l'Eglise et qui se réalise dans et par celle nommée ,le sacrament universal du salut" (LG 48; GS 45). L'idée du sacerdoce chrétien avait - dans la théologie préconciliaire - un caractère plus sociologique que théologique. On décrivait courrement un prêtre catholique en le comparant avec un "prêtre” païen, c.-à-d. avec un homme qui était „consacré aux choses divines" dans les différentes religions du monde. Le prêtre était donc und homme „pris d'entre les hommes” et „établi pour les hommes, dans leurs relations avec Dieu, afin d'offrir les dons et sacrifices pour les péchés" ( $\mathrm{Hbr} 5,1$ ). Le Concile Vatican II a permit aux théologiens de changer ce point de vue et décrire la prětrise (le sacerdoce) comme une "qualité de la personne qui la rende capable d'exercer une méditation sacrificielle"; le sacrifice sacerdotal étant, en même temps, rien d'autre que ,le don de soi-même ôffert à Dieu pour les autres". Cette définition du sacerdoce (et aussi du sacrifice) s'affirme quand il s'agit de l'Unique Grand Prêtre de Nouveau Testament, Jésus Christ, et - en manière subordonnée - vis-à-vis de la Vierge Marie et des fidèles qui ,deviennent un sacerdoce saint et royal, offrant des sacrifices spirituels à Dieu" (PO 2). Ainsi, au point de vue théologique, on peut dire seulement (et pleinement) de trois genres du sacerdoce dans l'Eglise: celui du Christ, de la Vierge et de tous les chrétiens. 
La situation se différencie quand on constate le fait d'institution par le Christ lui-même d'un sacrament (L'Ordre) qui incorpore les fidèles pas seulement au Christ (parce que tout cèla s'est fait dans le baptême), mais à son sacerdoce propre ainsi que les hommes ondonnés peuvent ré-présenter le Christ, l’Unique Grand Prětre, et Lui donner la possibilité de s'offrir à nouveau. Strictement parlant ces hommes ordonnés ne sont pas des prêtres à un titre personnel, mais seulement les outils et les instruments du Christ qui ne cesse pas d'exercer son propre sacerdoce par leur intermédiaire et qui donne ainsi aux fidèles possibilité de rejoindre leurs sacrifices personnels avec son sacrifice éternel qui se pérpetue sur les autels du monde tout entier.

En comparant ces deux sacerdoces: le sacerdoce commun des fidèles et le sacerdoce ministériel ou hiérarchique Vatican II souligne qu'ils sont ,ordonnés l'un à l'autre", „bien qu'il y ait entre eux différence essentielle et non seulement de degré": „l'un et l'autre, en effet, chacun selon son mode propre, participent de l'unique sacerdoce du Christ". Cependant, ,celui qui a reçu le sacerdoce ministériel jouit d'un pouvoir sacré pour former et conduire le peuple sacerdotal, pour faire, dans le rôle du Christ, le sacrifice eucharistique et l'offrir à Dieu au nom du peuple tout entier; les fidèles eux, de par le sacerdoce royal qui est le leur, concourent à l'offrande de Eucharistie et exercent leur sacerdoce par la réception des sacrements, la prière et l'action de grâces', le témoignage d'une vie sainte" (LG 10) etc., ainsi que toutes leurs activités, leurs prières et leurs entreprises apostoliques, leur' vie conjugale et familiale, leur labeurs quotidiens... tout cela devient, ,offrandes spirituelles agréables à Dieu par Jésus Christ; et dans la célébration eucharistique ces offrandes rejoignent l'oblation du Corps du Seigneur pour être offertes en toute piété au Père" (LG 34). Dans cette perspective-là les prêtres hiérarchiques sont ceux parmi les fidèles qui les apprennent „à offrir la victime divine à Dieu le Père dans le sacrifice de la messe, et à faire avec elle l'offrande de leur vie" (PO 5) pour le salut des autres; ils sont par conséquent ceux qui permettent aux chrétiens d'actualiser leur sacerdoce royal et d'unir les offranides personnelles avec l'Unique Sacrifice du Seigneur. Ills sont donc les serviteuns de Dieu, de l'Eglise et des fidèles, comme le souligne souvent Vatican II.

De cette conception du sacerdoce chrétien découlent des conséquences pratiques qui ne sont pas sans valeur pour la spécification des signes de la vocation sacerdotale. Ces signes, on peut les énumerer en disant que le jeune homme qui exercera prochainement la fonction du réprésentant de Christ lui-même doit se caractériser par: 1. le sens très profond de la transcendence qui sera nécessaire pour présenter le Christ et proclamer les mystères de Dieu; 2. la volonté bien déterminée de servir les hommes; 3. la prédilection pour l'Eucharistie qui est le sommet et la source de la vie de l'Eglise (icfr. SC 10), et qui constituera son service principal; 4. la vraie préoccupation de l'unité de l'Eglise qui doit être „aux yeux de tous et de chacun, le sacrement visible de cette unité salutaire" (LG 9); 5. la disponibilité qui exige souvent beaucoup de sacrifices personnels et par cela actualise son royal sacerdoce; 6 . la capacité de tenir une distance nécessaire vis-à-vis de choses et de personnes, 7. l'authenticité de la vie. 